\title{
Germline polymorphisms as modulators of cancer phenotypes
} Patrick Tan ${ }^{1,2}$

Address: ${ }^{1}$ Duke-NUS Graduate Medical School, 2 Jalan Bukit Merah, 169547, Singapore and ${ }^{2}$ Genome Institute of Singapore, 60 Biopolis Street, 138672, Singapore

Email: Patrick Tan - gmstanp@duke-nus.edu.sg

Published: 8 September 2008

BMC Medicine 2008, 6:27 doi:10.1186/1741-7015-6-27

This article is available from: http://www.biomedcentral.com/l74/-70/5/6/27

(C) 2008 Tan; licensee BioMed Central Ltd.

This is an Open Access article distributed under the terms of the Creative Commons Attribution License (http://creativecommons.org/licenses/by/2.0), which permits unrestricted use, distribution, and reproduction in any medium, provided the original work is properly cited.
Received: 12 August 2008

Accepted: 8 September 2008

\begin{abstract}
Identifying the complete repertoire of genes and genetic variants that regulate the pathogenesis and progression of human disease is a central goal of post-genomic biomedical research. In cancer, recent studies have shown that genome-wide association studies can be successfully used to identify germline polymorphisms associated with an individual's susceptibility to malignancy. In parallel to these reports, substantial work has also shown that patterns of somatic alterations in human tumors can be successfully employed to predict disease prognosis and treatment response. A paper by Van Ness et al. published this month in BMC Medicine reports the initial results of a multi-institutional consortium for multiple myeloma designed to evaluate the role of germline polymorphisms in influencing multiple myeloma clinical outcome. Applying a custom-designed single nucleotide polymorphism microarray to two separate patient cohorts, the investigators successfully identified specific combinations of germline polymorphisms significantly associated with early clinical relapse. These results raise the exciting possibility that besides somatically acquired alterations, germline genetic background may also exert an important influence on cancer patient prognosis and outcome. Future 'personalized medicine' strategies for cancer may thus require incorporating genomic information from both tumor cells and the non-malignant patient genome.
\end{abstract}

\section{Commentary}

\section{Germline variations and human health}

A major advancement of genetic research in recent years has been the explosion of genome-wide association studies (GWAS) in the literature from different investigators and laboratories [1]. The completion of the reference human genome sequence, and its subsequent comparison across different human sub-populations, has identified millions of genetic polymorphisms that differ between different individuals, families, and ethnic groups [2]. With the availability of increasingly affordable chip technologies for interrogating these polymorphisms en masse in individual genomes, it is now possible to consider identifying, on a comprehensive genome-wide scale, all genes and genetic variants associated with human disease.
In the area of cancer, GWAS studies have been performed for multiple different tumor types including breast, lung, and stomach cancers [3-5]. These studies have both reconfirmed previously known disease genes (eg FGFR2 in breast cancer) [3], and also identified novel genetic loci, such as TNRC9, MAP3K1, and LSP1 for breast cancer [3] and the nicotinic acetylcholine receptor subunits in lung cancer [4]. To date, the majority of reported GWAS studies have employed a case-control design, where affected individuals with a disease are compared against a matched population of non-affected normal controls. The genetic variants identified using such case-control designs thus represent 'disease susceptibility' loci that can either increase or decrease an individual's risk to developing disease. A report published this month in BMC Medicine by 
Van Ness et al. [6] seeks to extend this theme, by asking whether germline polymorphisms can influence not simply the onset of disease, but the actual course of disease prognosis in cancer.

\section{Somatic alterations as dominant drivers of cancer progression}

The focus of Van Ness et al. on the cancer patient germline is particularly notable when one considers how the concept of cancer as an acquired somatic disease has dominated the field. In this model, tumor cells are believed to arise as a consequence of accumulated genetic lesions, which cause the pathologic activation of oncogenes and inactivation of key tumor suppressor pathways [7]. Furthermore, multiple studies have already described various somatically-derived genomic 'signatures' in tumors that can predict both disease outcome and response to therapy, such as a 70 gene expression signature in breast tumors that can identify patients with particularly good prognoses [8], and EGFR mutations in lung cancers that can predict tumor response to EGFR-targeted therapies $[9,10]$. In contrast to the altered cancer genome, studies analyzing the germline analysis of cancer patients, for the most part, have been largely confined to the pharmacodynamic/pharmacokinetic (PK/PD) arena, where patients are genotyped for polymorphisms in various drug-metabolizing genes to identify individuals at greatest risk of incurring severe drug toxicities (eg UGT1A1 in irinotecan treatment) [11].

More recently, however, emerging evidence suggests that in addition to somatic alterations, germline variations may also play an important role in influencing cancer prognosis and disease outcome. This might occur if particular germline variants increase the risk of developing a particular cancer subtype intrinsically associated with poor prognosis. For example, in stomach cancer, polymorphisms in the PSCA gene have been shown to be associated with the development of diffuse-type gastric adenocarcinoma, a histologic variant traditionally associated with poor clinical outcome [5]. The influence of host genetic background on the development of cancers with differing metastatic traits has also been observed in mouse models of cancer [12]. Germline polymorphisms could also influence cancer prognosis by affecting the regulatory circuitry of cancer cells, by altering promoter-binding sites for important cancer-related genes such as $m d m 2$, a negative regulator of $p 53$ [13]. Although such studies are still relatively few in number, they do suggest that it may be time to initiate more systematic efforts to understand the specific role of germline genetic background in determining the course of cancer progression.

\section{Germline variants may affect outcome in multiple myeloma}

The report by Van Ness et al. provides promising initial data that this idea may indeed have scientific merit. This group has focused on multiple myeloma ( $\mathrm{MM})$, a hematopoetic malignancy of plasma B-cells. Although considered a uniformly fatal disease, individual MM patients are known to exhibit significant clinical heterogeneity in terms of disease morphology, time to progression and response to treatment [14]. To ask whether germline polymorphisms might underlie some aspect of this clinical heterogeneity, the investigators designed a customized single nucleotide polymorphism (SNP) array to measure genetic polymorphisms across $\sim 1000$ genes in biological pathways relevant to $\mathrm{MM}$ or $\mathrm{MM}$ therapy, including immunity and inflammatory pathways, and genes related to drug metabolism and transport. Although not a genome-wide approach, the use of a targeted array is not without its advantages. First, by making use of prior literature knowledge, the investigators were able to incorporate many SNPs in pathways and genes relevant for MM not represented on standard genome-wide SNP arrays. Second, the use of a smaller SNP set (3500 SNPs) allowed the study to be performed with relatively smaller numbers of patient samples while still preserving statistical power, compared with a typical GWAS study. Third, because the choice of treatment regimen is an important contributor to clinical outcome, the use of smaller numbers of patient samples also facilitates standardization of treatment therapies across independent patient cohorts.

The investigators applied their customized array to two separate cohorts of MM patients treated with comparable chemotherapeutic regimens. The recruitment of these patients was orchestrated through 'Bank on a Cure' (BOAC), a centralized collection agency for MM patient material from different corporative groups and institutional trials, established by expert researchers and clinicians in the MM field [15]. Using a series of computational training algorithms, the investigators showed that they could classify the patients on the basis of the germline SNP profiles into two distinct groups of 'good prognosis' (>3 year progression-free survival, PFS) vs 'bad prognosis' ( $<1$ year PFS) groups above random chance. Although this initial result will undoubtedly require further validation to assess its ultimate accuracy, several intriguing trends have already emerged from their data. Among these, the authors found that accurate classification was highly dependent on using a multiplex panel of SNPs rather than any single SNP in isolation, strongly suggesting that the factors driving disease outcome in $\mathrm{MM}$ are likely to be complex and multifactorial. Another interesting finding was that patient classification accuracy also increased when the analysis was restricted to non-synomymous SNPs, ie those SNPs causing amino acid differ- 


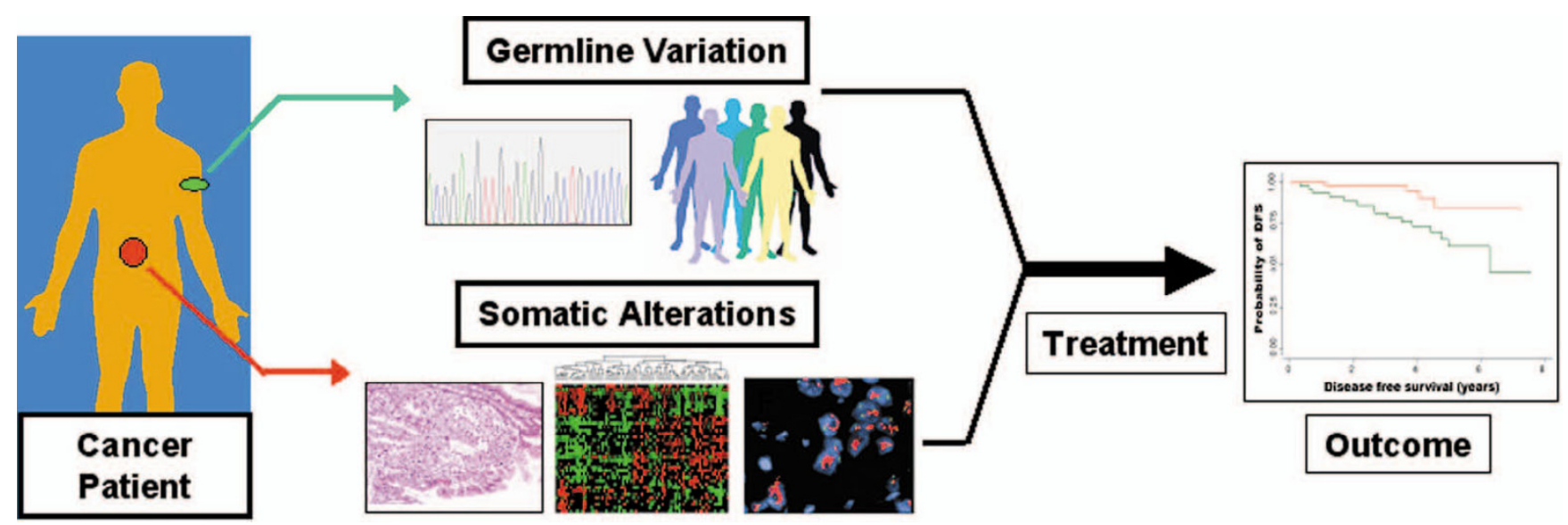

Figure I

Determinants of clinical outcome in cancer. The schematic outlines the interaction between germline genetic background and somatic alterations in influencing cancer outcome. Germline variations may result in differences between individuals in drug metabolizing activities, cancer pathways, and development of distinct molecular subtypes of cancer (top boxes). Alternatively, somatic alterations can cause differences in histopathology, gene expression, and gene amplifications and deletions (bottom boxes). Overlaid upon this germline/somatic interaction is the specific choice of treatment regimen. All these factors interplay to ultimately determine patient outcome (Kaplan-Meier survival curve on right). Pictures of human figures were adapted from http://commons.wikimedia.org/wiki/lmage:Wikicouple.svg. Pictures of FISH images and Kaplan-Meier survival curves were generated in the author's laboratory and previously used in [18].

ences in proteins. This may imply that stronger effects on clinical outcome are likely to be modulated through alterations in protein function, rather than by alterations in the regulatory pathways controlling the transcription of these genes.

\section{Challenges for the future}

Although obviously exploratory in nature, the promising results of this initial study have paved the way for more ambitious and rigorous experimental designs and projects. Some potential issues with the current study include the somewhat arbitrary threshold for defining the prognosis categories, which focuses on extreme cases $(<1$ year vs $>3$ years). It would have been interesting, for example, to ask if similar SNP associations were also observed if the analysis was repeated treating patient survival as a continuous variable. It could also be argued that the lack of using an unbiased genome-wide approach prohibited the investigators from discovering potentially novel genedisease associations, which might have shed further light on the regulatory pathways underlying MM. Ultimately, because this approach is relatively new, the study data will have to be further scrutinized in several other independent cohorts to assess the true prognostic power of these SNPs.

Finally, it will be fascinating to determine whether the stratification power provided by these germline SNPs reflects an enhanced propensity of certain patients to develop a particular poor or good prognosis 'molecular subtype' of $\mathrm{MM}$, since there is already a significant body of work describing various somatic alterations in $\mathrm{MM}$ that are predictive of clinical outcome $[16,17]$. Alternatively, it is also possible that these survival-associated SNPs may provide further stratification power beyond that observed by studying the somatic MM genome alone. In conclusion, this study by Van Ness is quite exciting and likely represents a model for similar studies in other cancers. It recognizes that the factors determining disease outcome in cancer are complex and multifactorial, ranging from the propensity of a cancer to proliferate and metastasize to how that cancer might respond to different types of therapy. One possibility for the future might be to test how such germline information can best be further integrated with somatic genomics to derive a holistic model for predicting outcome (Figure 1). Such information might directly translate to the development of new pharmaceutics, and diagnostic panels for personalized and predictive medicine.

\section{References}

I. McCarthy MI, Abecasis GR, Cardon LR, Goldstein DB, Little J, loannidis JPA, Hirschhorn JN: Genome-wide association studies for complex traits: consensus, uncertainty and challenges. Nat Rev Genet 2008, 9:356-369.

2. The International HapMap Consortium: A haplotype map of the human genome. Nature 2005, 437:I299-I320.

3. Easton DF, Pooley KA, Dunning AM, Pharoah PDP, Thompson D, Ballinger DG, Struewing JP, Morrison J, Field H, Luben R, Wareham $\mathrm{N}$, Ahmed S, Healey CS, Bowman R, The SEARCH collaborators, Meyer KB, Haiman CA, Kolonel LK, Henderson BE, Marchand LL, 
Brennan P, Sangrajrang S, Gaborieau V, Odefrey F, Shen CY, Wu PE, Wang HC, Eccles D, Evans DG, Peto J, Fletcher O, Johnson N, Seal S, Stratton MR, Rahman N, Chenevix-Trench G, Bojesen SE, Nordestgaard BG, Axelsson CK, Garcia-Closas M, Brinton L, Chanock S, Lissowska J, Peplonska B, Nevanlinna H, Fagerholm R, Eerola H, Kang D, Yoo KY, Noh DY, Ahn SH, Hunter DJ, Hankinson SE, Cox DG, Hall P, Wedren S, Liu J, Low YL, Bogdanova N, Schürmann P, Dörk T, Rob A, Tollenaar EM, Jacobi CE, Devilee P, Klijn JGM, Sigurdson AJ, Doody MM, Alexander BH, Zhang J, Cox A, Brock IW, MacPherson G, Reed MWR, Couch FJ, Goode EL, Olson JE, Meijers-Heijboer H, Ouweland AVD, Uitterlinden A, Rivadeneira F, Milne RL, Ribas G, GonzalezNeira A, Benitez J, Hopper JL, McCredie M, Southey M, Giles GG, Schroen C, Justenhoven C, Brauch H, Hamann U, Ko YD, Spurdle AB, Beesley J, Chen X, kConFab and AOCS Management Group, Mannermaa A, Kosma VM, Kataja V, Hartikainen J, Day NE, Cox DR, Ponder BAJ: Genome-wide association study identifies novel breast cancer susceptibility loci. Nature 2007, 447: $1087-1093$.

4. Hung RJ, McKay JD, Gaborieau V, Boffetta I P, Hashibe M, Zaridze D, Mukeria A, Szeszenia-Dabrowska N, Lissowska J, Rudnai P, Fabianova E, Mates D, Bencko V, Foretova L, Janout V, Chen C, Goodman G, Field JK, Liloglou T, Xinarianos G, Cassidy A, McLaughlin J, Liu G, Narod S, Krokan HE, Skorpen F, Elvestad MB, Hveem K, Vatten L, Linseisen J, Clavel-Chapelon F, Vineis P, Bueno-de-Mesquita HB, Lund E, Martinez C, Bingham S, Rasmuson T, Hainaut P, Riboli E, Ahrens W, Benhamou S, Lagiou P, Trichopoulos D, Holcátová I, Merletti F, Kjaerheim K, Agudo A, Macfarlane G, Talamini R, Simonato L, Lowry R, Conway DI, Znaor A, Healy C, Zelenika D, Boland A, Delepine M, Foglio M, Lechner D, Matsuda F, Blanche H, Gut I, Heath S, Lathrop $M$, Brennan P: A susceptibility locus for lung cancer maps to nicotinic acetylcholine receptor subunit genes on $15 q 25$. Nature 2008, 452:633-637.

5. Study Group of Millennium Genome Project for Cancer, Sakamoto H, Yoshimura K, Saeki N, Katai H, Shimoda T, Matsuno Y, Saito D, Sugimura $\mathrm{H}$, Tanioka $\mathrm{F}$, Kato $\mathrm{S}$, Matsukura N, Matsuda N, Nakamura T, Hyodo I, Nishina T, Yasui W, Hirose H, Hayashi M, Toshiro E, Ohnami S, Sekine A, Sato Y, Totsuka H, Ando M, Takemura R, Takahashi Y, Ohdaira M, Aoki K, Honmyo I, Chiku S, Aoyagi K, Sasaki H, Ohnami S, Yanagihara K, Yoon KA, Kook MC, Lee YS, Park SR, Kim CG, Choi IJ, Yoshida T, Nakamura Y, Hirohashi S: Genetic variation in PSCA is associated with susceptibility to diffuse-type gastric cancer. Nat Genet 2008, 40:730-740.

6. Van Ness B, Ramos C, Haznadar M, Hoering A, Haessler J, Crowley J, Jacobus S, Oken M, Rajkumar V, Greipp P, Barlogie B, Durie B, Katz M, Atluri G, Fang G, Gupta R, Steinbach M, Kumar V, Mushlin R, Johnson D, Morgan G: Genomic variation in myeloma: design, content, and initial application of the Bank On A Cure SNP Panel to detect associations with progression free survival. BMC Med 2008, 6:26.

7. Hanahan D, Weinberg RA: The hallmarks of cancer. Cell 2000, 100:57-70.

8. Vijver M Van de, He YD, Van't Veer LJ, Dai H, Hart AAM, Voskuil DW, Schreiber GJ, Peterse JL, Roberts C, Marton MJ, Parrish M, Atsma D, Witteveen A, Glas A, Delahaye L, Velde T van der, Bartelink $\mathrm{H}$, Rodenhuis S, Rutgers ET, Friend SH, Bernards R: A gene-expression signature as a predictor of survival in breast cancer. $N$ Engl I Med 2002, 347: 1999-2009.

9. Lynch TJ, Bell DW, Sordella R, Gurubhagavatula S, Okimoto RA, Brannigan BW, Harris PL, Haserlat SM, Supko JG, Haluska FG, Louis DN, Christiani DC, Settleman J, Haber DA: Activating mutations in the epidermal growth factor receptor underlying responsiveness of non-small-cell lung cancer to gefitinib. NEnglj Med 2004, 350:2129-2/39.

10. Paez JG, Jänne PA, Lee JC, Tracy S, Greulich H, Gabriel S, Herman P, Kaye FJ, Lindeman N, Boggon TJ, Naoki K, Sasaki H, Fujii Y, Eck MJ, Sellers WR, Johnson BE, Meyerson M: EGFR mutations in lung cancer: correlation with clinical response to gefitinib therapy. Science 2004, 304: I497-1500.

II. Innocenti F, Undevia SD, lyer L, Chen PX, Das S, Kocherginsky M, Karrison T, Janisch L, Ramírez J, Rudin CM, Vokes EE, Ratain MJ: Genetic variants in the UDP-glucuronosyltransferase IAI gene predict the risk of severe neutropenia of irinotecan. J Clin Oncol 2004, 22: 1 382-1388.

12. Hunter K, Welch DR, Liu ET: Genetic background is an important determinant of metastatic potential. Nat Genet 2003, 34:23-24.
13. Ohmiya N, Taguchi A, Mabuchi N, Itoh A, Hirooka Y, Niwa Y, Goto $H$ : MDM2 promoter polymorphism is associated with both an increased susceptibility to gastric carcinoma and poor prognosis. J Clin Oncol 2006, 24:4434-4440.

14. Tricot G, Spencer T, Spoon D, Sawyer J, Desikan R, Fassas A, Badros A, Zangari M, Munshi N, Anaissie E, Toor A, Barlogie B: Predicting long-term ( $>$ or $=5$ years) event-free survival in multiple myeloma patients following planned tandem autotransplants. Br J Haematol 200I, I 16:21 I-217.

15. Bank on a Cure [http://myeloma.org/main.jsp?type=arti cle\&tab id $=1$ \&menu id $=0$ \&id $=670]$

16. Carrasco DR, Tonon G, Huang Y, Zhang Y, Sinha R, Feng B, Stewart JP, Zhan F, Khatry D, Protopopova M, Protopopov A, Sukhdeo K, Hanamura I, Stephens O, Barlogie B, Anderson KC, Chin L, Shaughnessy JD Jr, Brennan C, DePinho RA: High-resolution genomic profiles define distinct clinico-pathogenetic subgroups of multiple myeloma patients. Cancer Cell 2006, 9:313-325.

17. Zhan F, Huang Y, Colla S, Stewart JP, Hanamura I, Gupta S, Epstein J, Yaccoby S, Sawyer J, Burington B, Anaissie E, Hollmig K, PinedaRoman M, Tricot G, van Rhee F, Walker R, Zangari M, Crowley J, Barlogie B, Shaughnessy JD Jr: The molecular classification of multiple myeloma. Blood 2006, 108:2020-2028.

18. Tan BK, Tan LK, Yu K, Tan PH, Lee M, Sii LH, Wong CY, Ho GH, Yeo AW, Chow PK, Koong HN, Yong WS, Lim DT, Ooi LL, Soo KC, Tan $P$ : Clinical validation of a customized multiple signature microarray for breast cancer. Clin Cancer Res 2008, I 4:46 I-469.

\section{Pre-publication history}

The pre-publication history for this paper can be accessed here:

http://www.biomedcentral.com/1741-7015/6/27/prepub
Publish with Biomed Central and every scientist can read your work free of charge

"BioMed Central will be the most significant development for disseminating the results of biomedical research in our lifetime. "

Sir Paul Nurse, Cancer Research UK

Your research papers will be:

- available free of charge to the entire biomedical community

- peer reviewed and published immediately upon acceptance

- cited in PubMed and archived on PubMed Central

- yours - you keep the copyright 